Research article

\title{
The Gingers of the north coastal Andhra Pradesh, India
}

\author{
Prameela R. ${ }^{1 *}$ and Venkaiah $\mathbf{M .}^{2}$ \\ ${ }^{1}$ M. R. Degree College, Vizianagaram, Andhra Pradeah-535002, India \\ ${ }^{2}$ Department of Botany, Andhra University, Visakhapatnam, Andhra Pradeah-530003, India \\ *Corresponding Author: prameelachris@yahoo.com \\ [Accepted: 31 March 2018]
}

\begin{abstract}
The north coastal Andhra Pradesh is one of the important agro-climatic zones of Andhra Pradesh with the high altitude hill zones. Forest range is considered as a basic unit in which harbours good patches of vegetation. Some important study areas are Chintapally, Narsipatnam, Anantagiri, Araku, Kurupam, Gummalakshmipuram, Parvathipuram, Salur and Palakonda. As zingibers are shade loving plants, they mostly grow in damp and humid shady places. Some species can fully expose to the sun, and grow on high elevation. Very few species cultivated in plain areas for the commercial and domestic purpose (Ginger, Turmeric and Ornamentals etc.). North coastal Andhra Pradesh covers the 20 percent of the forest area (6,51,537 ha), with rich sources of flora and fauna. Zingibers possess great medicinal properties like expectorant, acrid, aphrodisiac, thermogenic, febrifuge, appetiser, carminative, antihelmintic etc. They are useful in vitiated conditions of vata, pitta and kapha, respiratory diseases, digestive complaints, and Skin diseases. Because of the great medicinal properties of zingibers, they are widely used by the people from all parts of the world, and also pharmacological studies are extensively conducted on these plants.
\end{abstract}

Keywords: Ginger - Zingiberaceae - Hill regions - North coastal Andhra Pradesh.

[Cite as: Prameela R \& Venkaiah M (2018) The Gingers of the north coastal Andhra Pradesh, India. Tropical Plant Research 5(1): 53-60]

\section{INTRODUCTION}

Family Zingiberaceae having some peculiar and common characters like Rhizomatous perennial rootstock. Distichous and ligulate leaves. Flowers in racemes, heads or cymes. Flowers zygomorphic, bracteates and bracteolate. Sepals three, united at the base. Petals three, separate. Fertile stamen one and 1 to 3 petaloids staminodes formed into a lip. Ovary inferior, tricarpellary, trilocular. Fruit loculisidal capsule (Gamble 19151936). Zingiberaceae is one of the largest, medicinally important families among the monocots (Das et al. 2013, Kirtikar \& Basu 2003). $90 \%$ of the Zingibers are used as herbal medicine in addition to medicine they provide important natural resources like food, spices, dyes, perfume, essential oils and aesthetics to man (Sirirugsa 1999). Zingiber officinale, for example, has been used for many years as spice and in traditional forms of medicine to treat a variety of diseases. Throughout the world, Zingiberaceae family contains about 52 genera with 1587 species (The plant List 2017). The present study was carried out on locally available plants. There are 8 genera and 26 species are studied from this area. Some gingers like Curcuma species, Kaempfera species and Cheilocostus speciosus are undergone for dormancy for 6 to 7 months during winter and summer season from December to May. After dormancy period they will germinate in the rainy season. For this reason all the dormant gingers are blossoms in the rainy season from July to October or November, after flowering they are undergoing to dormancy.

Present study area, north coastal Andhra Pradesh is one of the important Agro-climatic zones of Andhra Pradesh with the high altitude hill zones. The region extends an area of 23,48,612 ha. North coastal Andhra Pradesh comprises the three districts namely Srikakulam, Vizianagaram and Visakhapatnam. In which Visakhapatnam is the largest district occupying nearly $47 \%$ of the area in the region. Some important study areas are Chintapally, Narsipatnam, Anantagiri, Araku, Kurupam, Gummalakshmipuram, Parvathipuram, Salur and Palakonda. 
This region is divided into coastal land, plains and hilly areas. Major river systems are there like Vamsadhara, Nagavalli, Janjavathi, Champavathi, Vegavathi, Vattigadda, Gosthani, Sarada, Varaha and Thandava. In addition to rivers there are number of ponds occurred in this region. Forest range is considered as basic unit in which harbours good patches of vegetation. According to the forest department the area under study includes five forest divisions with 21 Forest Ranges covering forest area of 6, 51,537 ha (nearly 20\%).

\title{
MATERIAL \& METHODS
}

The live plants were collected from the study area that is north coastal Andhra Pradesh situated on the East Coast known as the Coromandol coast and lies approximately between $17^{\circ} 10^{\prime}$ to $19^{\circ} 10^{\prime} \mathrm{N}$ latitudes and $81^{\circ} 53^{\prime}$ to $84^{\circ} 50^{\prime}$ E longitudes, and successfully conserved at Botanical garden, Department of Botany, M.R.Degree college (Formerly M.R.College for women), Vizianagaram. Literature was collected from different sources such as Ayurvedic classical texts, floras, books, journals and internet databases to make a list of medicinal plants classified under Zingiberaceae (Rao \& Sriramulu 1986, Sharma et al. 1996, Pullaiah 1998, Venkaiah 2004, SubbaRao \& Kumari 2008).

\section{RESULTS AND DISCUSSION}

\section{Plant Description}

Alpinia calcarata (Haw.) Roscoe, Trans. Linn. Soc. London 8: 347.1807; Gamble vol. 3.1492; Indian Medicinal Plants vol. 4.24471918

(Fig. 1A)

Perennial 1 rhizomatous herbs, rhizome slightly aromatic, light yellow in colour; leafy stem $0.7-1.2 \mathrm{~m}$ high; leaves linear-lanceolate, acuminate, 30-40 cm long, 3.5-4.0 cm width, margin scaberulous, brown; leaf sheath 7-8 cm long open at one side, ligule 1.0-1.3 cm long, brown; inflorescence terminal, panicle, rhachis pubescent. Calyx tubular, scaberulous, mouth ciliate, petals linear, white; stamen single, dithecous, staminode or lip attractive, red and yellow, emarginated; ovary pubescent, inferior, tri-carpellary.

Common name: Snap ginger.

Uses: Indian ginger is useful in arthritis, inflammations, stomatopathy, asthma, bronchitis, hick-up, obesity, diabetes, dyspepsia and intermittent fevers.

Alpinia galanga (L.) Willd., Sp. Pl. 1: 12.1797; Maha. Fl. 67; Gamble vol. 3.1492.

Perennial herbs, tuberous, slightly aromatic; leaves oblong-lanceolate, acute or acuminate, margins white, glabrous, upper surface green lower surface pale green, ligule short, rounded, ciliate; flower in open panicle, 10 $\mathrm{cm}$ in long, rhachis puberulous; flowers greenish white, lip veined with red, orbicular, spathulate, apex shortly 2-lobed, claw slender with 2 subulate glands at the base, ovary glabrous; capsule orange red.

Common name: Blue ginger or Thai ginger or Chinese ginger.

Uses: Improves appetite, useful in vata, bronchitis and diseases of the heart, head-ache, rheumatic pains, pain in the chest, burning of the liver, diabetes, diseases of the kidney. It is disinfectant, used to destroy bad smells in the mouth.

\begin{abstract}
Alpinia malaccensis (Burm.f.) Roscoe, Trans. Linn. Soc. London 8: 345 1807. Gamble vol. 3.1493; MV.205.
Leafy stem up to $3 \mathrm{~m}$ high, leaves shortly petiole, petioles, sheathes pubiscent oblong lanceolate, acuminate, hairy on the midrib beneath; the margins often densely villous; leaves distichous, racemes terminal, up to $0.3 \mathrm{~m}$ long; rachis villous, bracts large, white, petaloid, coreaceous, flowers white with pinkish striations in the centre, labellum yellow, centre variegated deep-red and yellow, hirsute at base with in with 2 papillose swellings at base within, stamen 1, pubescent on the inner side of the filament; staminodes 2, ovary hirsute; epigynous glands 5, free; style long, pubescent, stigma funnel shaped, villous.
\end{abstract}

Common name: Adavi allamu

Uses: Rhizomes and leaves yield essential oils. Rhizomes employed for treating sores.

Alpinia nutans Roscoe, Exot. Bot. 2: 93.1806; Indian Medicinal Plants vol. 4. 2448.

(Fig. 1B)

Perennial rhizomatous shrubs, leafy stem grows upto $1.8 \mathrm{~m}$ high, leaves $40-60 \mathrm{~cm}$ long, $8.0-15 \mathrm{~cm}$ width, pubescent beneath, inflorescence terminal, panicle, 15-30 cm; rhachis very hairy, lower branches bearing 2-3 crowded flowers, bracteoles broad, navicular; corolla segments oblong, white tipped with pink. Lip broad, variegated with red and yellow and emarginated.

Common name: Shell flower ginger.

Uses: Improves appetite, useful in kapha and vata, bronchitis, asthma, indigestion and diseases of the heart, www.tropicalplantresearch.com 
head-ache, rheumatic pains, pain in the chest, burning of the liver, diabetes, diseases of the kidney. It is disinfectant, used to destroy bad smells in the mouth.

Alpinia purpurata (Vieill.) K.Schum., Pflanzenr. IV, 46: 323.1904; Botanica 84.

Perennial rhizomatous shrubs, leafy stem grows up to $2 \mathrm{~m}$ high, leaves $10-15 \mathrm{~cm}$ long, $4.0-6.0 \mathrm{~cm}$ width, inflorescence terminal, showy red spikes. Bracts red colour, single flowered, flowers white, new plantlets sprout among the flower bracts and take root when the dying flower stems fall to the ground under the weight of the growing plantlets.

Common name: Red ginger.

Uses: It is an ornamental plant grown in the gardens for their beautiful flowers.

Curcuma amada Roxb., Asiat. Res. 11: 341.1810; Gamble vol. 3.1482; Indian Medicinal Plants vol. 4.2422.

Root stock large, sessile tubers thick, cylindric or ellipsoid pale yellow inside, tufted leaves, 0.6-0.9 m high, leaves with long petiole, lamina oblong lanceolate, acute or acuminate, glabrous, green on both sides, tapering at both ends, up to $24 \mathrm{~cm}$ long, $9.0 \mathrm{~cm}$ wide petioles as long; inflorescence arise from the root stock, flowers on spikes in the centre of the tuft of leaves; peduncle $9.0 \mathrm{~cm}$ long or more, flowering bracts $1.5 \mathrm{~cm}$ long, greenish white; bracts of coma longer and narrower, tinged with pink or red; corolla white or pale yellow; lip semi elliptic, 3-lobed, mid lobe emarginated.

Common name: Mango ginger, Mamidiallamu.

Uses: Rhizome is cooling, appetiser, antipyretic, laxative, all kinds itching and skin diseases, bronchitis, asthma and hick-up. And also useful in troubles in the mouth and the ear.

Curcuma aromatica Salisb., Parad. Lond. t. 96.1808; Gamble vol. 3.1482; Indian Medicinal Plants vol. 4.2419.

Perennial rhizomatous, palmately branched, sessile annulate biennial tubers, aromatic and yellow inside; leaves oblong-lanceolate, petioles as long as or longer then the blade. Flowers fragrant, shorter than the bracts, flowering bracts ovate, recurved, cymbiform, rounded at the tip, tinged with red or pink; calyx irregularly 3lobed. Lip yellow, obovate, 3 - lobed

Common name: Wild Turmeric, kasturi pasupu.

Uses: Rhizomes used for bruises and sprains.

Curcuma caesia Roxb., Asiat. Res. 11: 334.1810; Indian Medicinal Plants vol. 4.2422.

Leaves broadly lanceolate or oblong, glabrous, with a deep ferruginous purple cloud down the middle which penetrates to the lower surface, petiole and sheath about as long as the blade; spikes appearing rather before the leaves. Flowering bracts green with a ferruginous tinge, coma deep bright red, tending to crimson. Flowers pale yellow, reddish at the outer border.

Common name: Black turmeric, Nallapasupu, or Manupasupu.

Uses: Dried rhizomes and leaves of are used in piles, leprosy asthma, cancer, wounds, impotency,fertility, tooth ache, vomiting, and allergies.

Curcuma longa L., Sp. Pl. 2.1753; Maha. Fl. 77; Gamble vol. 3.1482.

(Fig. 1C)

Large rhizomatous herbs, rhizome ovoid, sessile cylindric, aromatic, bright orange coloured inside; leaves radical, oblong, caudate acuminate, tapering to the base uo to $25-30 \mathrm{~cm}$ long $12 \mathrm{~cm}$ wide; flowering spikes rising in the centre of a previously formed tuft of leaves 10-15 cm long, peduncle clothed in appressed bracts; flowers in a dense, bracteate, stribiliform spike, terminating in a coma of enlarged sterile bracts, white coloured, tip tinged with green; fertile bracts forming pouches enclosing single flower, yellow; calyx short, cylindric, minutely toothed; corolla funnel shaped, lobes 3, ovate, upper one longer and hooded; lateral staminodes petaloid, connate with the filament, anterior staminode formed into the lip, orbicular, yellow; fertile stamen one, filament short, anther cells 2, spurred at the base; ovary 3-celled, ovules many, axile placentation, style filiform, stigma ciliate.

Common name: Turmeric.

Uses: Rhizome is a source of turmeric, used as a condiment and a colouring agent, stimulant, carminative, stomachic and depurative.

Curcuma pseudomontana J. Graham, Cat. Pl. Bombay 210.1839; Gamble vol. 3.1483; AP. Fl.964. (Fig. 1D)

Root stock small, stem less herbs, up to $40 \mathrm{~cm}$ high, rhizomes conical, bearing stalked sub globose tubers, pure white inside, black on drying, leaves oblong-lanceolate, acute or shortly acuminate, entire, acute at base, 
glabrous, petioles $6.0-7.0 \mathrm{~cm}$ long lamina, $7.0-8.0 \mathrm{~cm}$ long, spikes up to $10 \times 5 \mathrm{~cm}$, arising from the centre of atuft of leaves; upper bracts sterile, pink or pinkish white, lowering bracts smaller than the sterile ones, white with purple tip, saccate, each bearing 2-3 yellow flowers, calyx membranous, cream to white, 3 -lobed, corolla yellow, funnel shaped, lobes 3, subequal; dorsal lobe longer than the other two, stamen 1; filament minute, connate with 2 yellow, petaloidstaminodes; ovary hirsute; style filiform with 2 nectary glands at base; stigma small, lobed.

Common name: Hill turmeric, Adavipasupu.

Uses: Rhizome yield a form of arrowroot, it cures jaundice and swellings.

Elettaria cardamomum (L.) Maton, Trans. Linn. Soc. London 10: 254.1811; Gamble vol. 3.1491.

Rootstock, woody, brown, stem $2 \mathrm{~m}$ high, clother below with spongy sheaths, leaves linear-lanceolate, acuminate, tip cuspidate, soft hairy, margins white, hirsute, short petiole, ligule membranous $5 \mathrm{~cm}$ long, pinkish red, $30 \mathrm{~cm}$ long, $5 \mathrm{~cm}$ width, young plants pinkish red, panicles several up to $0.6 \mathrm{~m}$, erect or prostrate: bracts $6-$ 7 flowered linear-oblong, obtuse, about $4 \mathrm{~cm}$ long, coralla tube white, shortly exserted, lobes $1 \mathrm{~cm}$ long, lip longer, white striped with violet, capsule subtrigonous, about $0.7 \mathrm{~cm}$ long.

Common name: Cardamum, Elachi.

Uses: Cardamom is used for digestion problems including heartburn, intestinal spasms, intestinal gas, constipation, liver and gallbladder complaints, and loss of appetite. It is also used for common cold, cough, bronchitis, sore mouth and throat, and tendency toward infection. Some people use cardamom as a stimulant and for urinary problems.In foods, cardamom is used as a spice in many parts of the world.

Globba marantina L., Mant. Pl. 2: 170.1771; Gamble vol. 3.1481.

(Fig. 1E)

Herbs, erect, up to $45-85 \mathrm{~cm}$ long, drooping; roots fascicled, tuberous, leaves $12 \times 4 \mathrm{~cm}$, caudate, pubescent below; sheaths glabrous, margins ciliate; inflorescence lax flowered spike, flowers orange, calyx funnel shaped, corolla yellow, filaments long.

Common name: Dancing ladies ginger.

Uses: Bulbils are used as a spice and to stimulate the appetite.

Globba sessiliflora Sims., Bot. Mag. 35: t. 1428.1811; Gamble vol. 3.1480.

Erect herbs, about $40 \mathrm{~cm}$ high, leaves elliptic, oblong-lanceolate, pubescent below; flowers deep yellow in spikes; capsules smooth.

Common name: Stalkless swan flower.

Globba orixensis var. pubescens SubbaRao \& Kumari, Fl. Visakhapatnam Distr. 2: 259.2008.

Erect herbs up to $70 \mathrm{~cm}$ long; leaves few up to $24 \mathrm{~cm}$ long, $7 \mathrm{~cm}$ wide, oblong lanceolate, acuminate or caudate, entire, cuneate at base, glabrous above, pubescent below; petioles long and puberulous; ligules $0.3 \mathrm{~cm}$ long, membranous ciliate; sheaths $15.5 \mathrm{~cm}$ long puberulous, panicles $30 \mathrm{~cm}$ long, lax flowered, puberulous, flowers sessile, bright yellow, staminodes 2 petaloid; lip deeply bifid, deflexed, spotted red, ovary warted, glandular; stigma clavate, nectary glands linear.

Note: This taxon is nearer to G. orixensis Roxb., but differs from it in having long caudate leaves with pubescent and glaucous under surface.

Hedychium coronarium J.Koenig, Observ. Bot. 3: 73.1783; Gamble vol. 3.1484; MV. 204; AP. Fl. vol. 3:966; House plants 49.

(Fig. 1F)

Root stock stout horizontal, fleshy, jointed; stem erect, leafy up to $5 \mathrm{ft}$ high, leaves sessile, lanceolate, $25 \times 7$ $\mathrm{cm}$, acuminate, narrowed at base; flowers, pure white, scented in terminal spikes 10-20 cm long, bracts oblong subcoriaceous; lip large, 2 fid, white tinged with yellow, ovary 3-celled, ovules many, fruit globose 3-valved capsule, seeds many, small with a lacerate aril.

Common name: Butterfly ginger, White ginger lily.

Uses: Aerial stem suitable for pulp making. Rhizomes yield a volatile oil, they are used as a febrifuge, tonic, excitantand antirheumatic. Leaves eaten by cattle.

Hedychium flavescens Carey ex Roscoe, Monandr. Pl. Scitam. t. 50.1824; Gamble vol. 3.1485; AP. Fl. vol. 3: 966.

Root stock stout horizontal, fleshy, jointed; stem erect, leafy up to $5 \mathrm{ft}$ high, leaves sessile, lanceolate, $25 \times 7$ $\mathrm{cm}$, acuminate, narrowed at base, hirsute on lower surface; flowers in terminal spikes 10-20 cm long, flowers 
yellow and aromatic. Bracts broad, tip round, 2 to 3 flowered and green. Calyx tubular, corolla tube curved, petals 3 , linear, lateral staminodes two, lanceolate, lip bilobed, lobes rounded, fertile stamen longer than the lip, pollen round. Ovary villous, tri-carpellary, tri locular, two ovules in each locule.

Common name: Yellow ginger.

Uses: flowers highly aromatic. Blossoms at evening.

Kaempferia galanga L., Sp. Pl. 3.1753; Gamble vol. 3.1483; Maha. Fl.82.

(Fig. 1G)

Small, stem less herbs; root fibers ending in smaller tubers in addition to the large ones leaves 2, spread flat on the ground; orbicular to rotund ovate; flowers 6-12 between the 2 leaves; bracts lanceolate, flowers fragrant; calyx short, cylindric, splitting down one side; corolla tube long three, equal; staminodes broad, petaloid, perfect stamen one, anther two celled, on a wide connective produced above into a petaloid crest, lip broad, white with a purple or lilac spot on each side of the lip; ovary tri carpellary, tri locular, ovules many, axile placentation, style long, filiform; stigma turbinate.

Common name: Aromatic ginger, Sand ginger, resurrection lily.

Uses: Rhizomes stimulating, expectorant, carminative, diuretic, given in cough and pectoral affections; also used to relieve irritation produced by stinging caterpillars. Rhizomes yield a volatile oil.

Kaempferia roscoeana Wall., Bot. Reg. 14: t. 1212.1829; House plants 55.

(Fig. 1H)

Stemless with fleshy rhizome, leaves 2 , sometimes 1 or 3, blade very broad-ovate, $10 \times 13 \mathrm{~cm}$, spreading horizontally, upper surface beautiful shining bronzy-chocolate taffeta, iridescently veined and zoned pale green like peacock tail, purplish and shining-grey beneath, flowers lilac with white eye.

Common name: Peacock ginger.

Uses: Ornamental plant, grown in the gardens for their beautiful foliage.

Kaempferia rotunda Linn., Sp. Pl. 3 1753; Gamble vol. 3.1484; Ind. Med. Plants 2428; Use full plants 307.

Rootstock corm, root fibres fleshy; leaves large, erect, oblong; flowering without leaves; flowers arise from the crowded radical spike, it borne from the underground tuber; spike produces $10-12$ flowers, only one flower opening at a time; petals 3 , linear, longer than corolla tube, staminodes 2 , oblong, acute, 5-6 cm long, as long as the lip, white; lip lilac, 5-6 cm long and 5-6 cm broad, 2- fid, segments sub orbicular; fertile stamen $2-3 \mathrm{~cm}$ long, deeply 2-fid, lobes lanceolate.

Common name: Bhoomi champa, konda kaluva.

Uses: Corm considered stomachic and used in gastric complaints. Corms used as local application on tumours, swellings and wounds, they help to remove blood clots and other purulent matter in the body.

Zingiber capitatum Roxb., Asiat. Res. 11: 348.1810; AP. Fl. vol. 3: 967.

Erect herbs up to $2 \mathrm{~m}$ long, leaves erect, spreading, up to $55.5 \times 2.6 \mathrm{~cm}$, linear-lanceolate, acuminate, entire, glabrous above, pubescent on the lower surface especially on the midrib, sessile; sheaths up to $40 \times 1 \mathrm{~cm}$, striate, pubescent without; ligule up to $0.3 \mathrm{~cm}$ long, pubescent; spikes terminal, dense, up to $18 \times 4.1 \mathrm{~cm}$, oblong-ellipsoid; bracts red, up to $5.3 \times 1.8 \mathrm{~cm}$, margins thin, brown; lower bracats ovate, obtuse, pubescent without; upper ones narrower, acute, pubescent, capsules red, up to $2.2 \times 1.0 \mathrm{~cm}$, ovate, striate, pubescent, seeds up to $0.25 \mathrm{~cm}$ long, black, aril white and lacerated.

Common name: Wild ginger.

Zingiber montanum (J.Koenig) Link ex A. Dietr., Sp. Pl. 1: 52.1831; Gamble vol. 3.1489; Indian Medicinal

Plants vol. 4.2439.

(Fig. 1I)

Perennial rhizomatous herbs; root fibers ending in smaller tubers in addition to the large ones; rhizome yellow inside, aromatic, tasting of camphor, leafy stem $3 \mathrm{ft}$ high, leaves subsessile, oblong-lanceolate, distichous; Inflorescence arise from the rootstock, along with leaves, spikes dence, fusiform or oblong-ellipsoid, peduncles long, shorter than the leafystem; bracts broadly ovate, bright red or greenish red, single flower, calyxcylindric, shortly 3- lobed; corolla tubular, lobes lanceolate, the upper concave; perfect stamen single, filament short, anther dithecous, connective produced into a narrow beak as long as anther cells, there are no lateral staminodes, anterior staminode formed into the lip, lip broad, orbicular, yellow Spikes possess turmeric odour, fluid gelatinous;

Common name: Cassumunar ginger, Karallamu or Karupasupu.

Uses: It is a good expectorant, remedy for cough and cold, also used as stimulant and carminative. It possess the both the ginger and turmeric characters.

www.tropicalplantresearch.com 
Zingiber officinale Roscoe, Trans. Linn. Soc. London 8: 348.1807; Gamble vol. 3.1489; Maha. Fl. 83. (Fig. 1J)

Rhizome stout tuberous with erect leafy stems 0.6-1.2 $\mathrm{m}$ high, leaves narrow, distichous, subsessile on the sheaths, linear-lanceolate, 1-2 cm wide, glabrous, flowers yellowish with a small dark purple or purplish black lip, in radical spikes 3-7 cm long and $2.5 \mathrm{~cm}$ wide on peduncles $15-30 \mathrm{~cm}$ long, stamen dark purple, as long as the lip, rather shorter than the corolla.

Common name: The Ginger.

Uses: Rhizome is highly esteemed as a spice for its characteristic odour and warm pungent taste. Dried ginger is widely used for flavouring foods. Ginger oil is an essential oil used in perfumery.
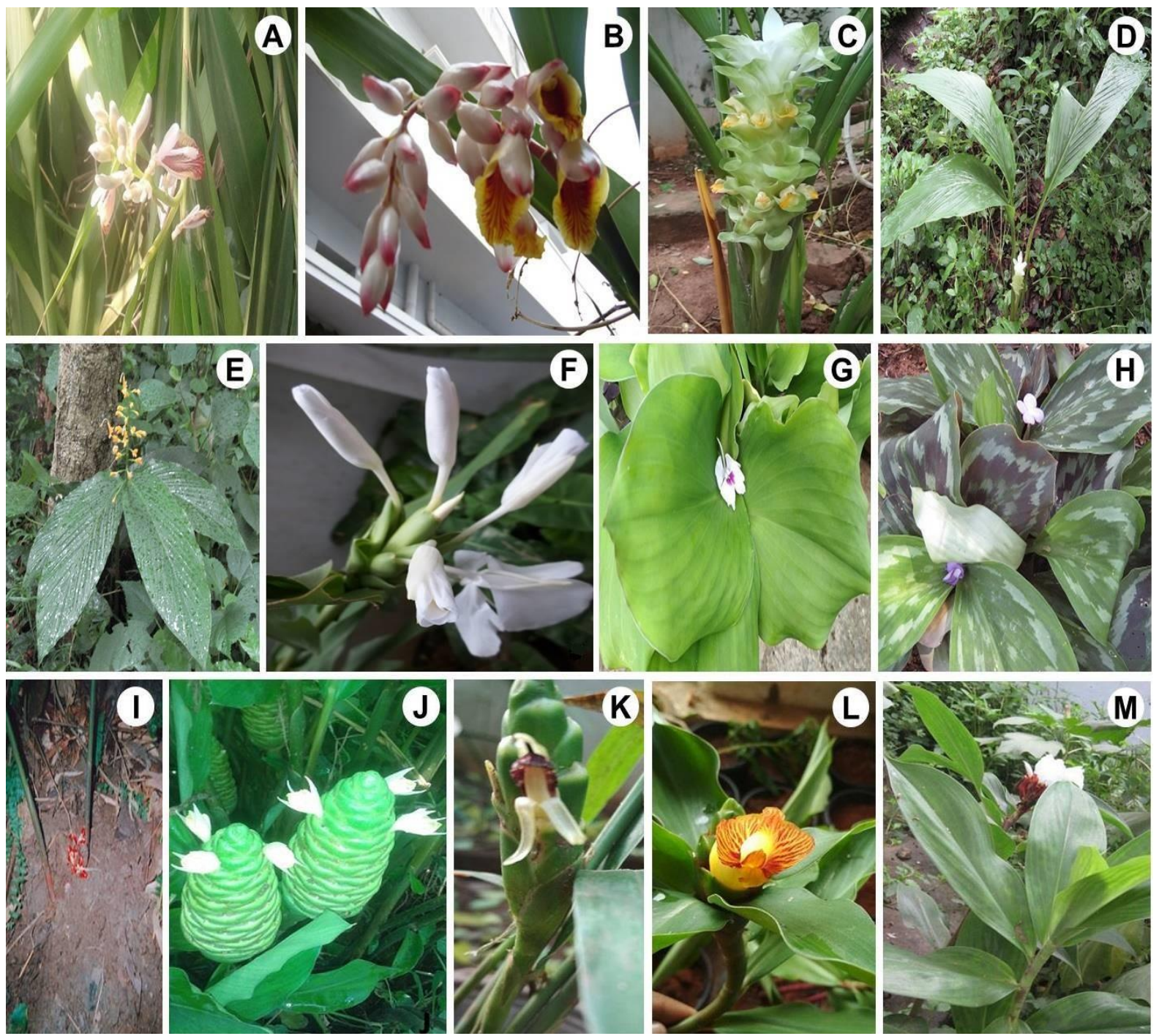

Figure 1. Some gingers of north coastal Andhra Pradesh: A, Alpinia calcarata (Haw.) Roscoe; B, Alpinia nutans Roscoe; C, Curcuma longa L.; D, Curcuma pseudomontana J. Graham; E, Globba marantina L.; F, Hedychium coronarium J.Koenig; G, Kaempferia galanga L.; H, Kaempferia roscoeana Wall.; I, Zingiber montanum (J.Koenig) Link ex A. Dietr.; J, Zingiber officinale Roscoe; K, Zingiber roseum (Roxb.) Roscoe; L, Costus pictus D.Don.; M, Cheilocostus speciosus (J.Koenig) C.D.Specht.

Zingiber roseum (Roxb.) Roscoe, Trans. Linn. Soc. London 8: 348.1807; Gamble vol. 3.1489; AP. Fl. vol. 3: 968.

(Fig. 1K)

Erect herbs up to $1.5 \mathrm{~cm}$ long, leaves distichous $40 \times 8 \mathrm{~cm}$ long oblong-lanceolate, acuminate, entire narrowed at base, glabrous above, pubescent below sheaths $28 \mathrm{~cm}$ long, striate, pubescent; ligule membranous $1.5 \mathrm{~cm}$ long bilobed, sparsely silky; spikes dense, sessile; bracts red, silky pubescent, flowers $6 \mathrm{~cm}$ long, calyx green, tubular, corolla lobes sub equal, pale red, tube white; labellum white recurved, lateral lobes yellow very short, rounded, stamen bright yellow, arching over the labellum, ovary oblong, villous, style with 2 subulate glands at base; stigma pubescent, capsule $2.5 \mathrm{~cm}$ long 3-angled; pubescent when young, seeds ovoid, arillate, brown, striate. 
Common name: Wild ginger.

Uses: Used for digestion, fevers, rheumatism and to relieve giddiness.

Zingiber wightianum Thwaites, Enum. Pl. Zeyl. 315.1861; Gamble vol. 3.1489; AP. Fl. vol. 3: 968.

Erect herbs $2 \mathrm{~m}$ high, leaves $30 \times 7 \mathrm{~cm}$, oblong-lanceolate, acuminate, entire,cuneate at base, glabrous above, pubescent to glabrescent on lower surface, subsessile; spikes arising from rhizomes, peduncles up to 8 $\mathrm{cm}$ long, clothed with membranous sheaths; bracts green; bracteoles similar to bracts, calyx green, corolla yellow, lobes 3 subequal; labellum obovate, emarginated, yellow, spotted and striped purple, anther subsessile, arching over the labellum; beak $0.8 \mathrm{~cm}$ long ovary sub globose; style, bent at apex, with 2 subulate nectary glands at base; stigma ciliate.

Common name: Mountain ginger

Uses: It has a higher protective effect on liver.

Costaceae was included in the family zingiberaceae in earlier classification because both Costaceae and zingiberaceae shared the same inflorescence and floral characters. The separation between this two families were due to the lack of aromatic oils, branched aerial stems, spiromonostichous leaves with a closed sheath and tubular in Costaceae.

Costus pictus D.Don., Edwards's Bot. Reg. 19: t. 15941833.

(Fig. 1L)

Herb, an erect plant 1-2 ft high, root stock rhizomatous, stems spirally twisted so that leaves appear spirally arranged, stem lower half purple red, upper half green; inflorescence cone, bracts compactly arranged, green; flowers yellow. Plants propagated by rhizomes and stem cuttings.

Common name: Insulin plant.

Uses: This plant is used by diabetic patients.

Cheilocostus speciosus (J.Koenig) C.D.Specht, Taxon 55: 1592006.

Costus speciosus J.Koening. Gamble vol. 3.1490; Maha. Fl. 70; MV 181; HS 458.

(Fig. 1M)

Herb, an erect plant $1-2 \mathrm{ft}$ high, root stock rhizomatous, stems spirally twisted so that leaves appear spirally arranged, stem lower half green, upper half red; in every twist there are 3 leaves appear, leaves oblanceolate 14 $\mathrm{cm}$ long, $5 \mathrm{~cm}$ wide acuminate or cuspidate; cusp $0.4 \mathrm{~cm}$ long, white, glabrous above silky pubescent beneath, leaves shining, flowers white with yellow centre, short lived, in very dense spikes, bracts ovate, bright red, lip sub orbicular, white with a yellow centre. Plants propagated by rhizomes.

Common name: Spiral ginger.

\section{CONCLUSION}

Earlier studies shows that, in the Flora of Andhra Pradesh there are 15 species belongs to 6 genera, in flora of srikakulam district there are 8 species with 5 genera, in the flora of Vizianagaram district there are 7 species with 5 genera and in the flora of Visakhapatnam district there are 9 species with 6 genera.

From the present study, twenty six species belongs to 8 genera were studied from the north coastal Andhra Pradesh region.The eight genera are Alpinia with 5 spp., Curcuma with 5 spp., Elettaria with 1 sp., Globba with 3 spp., Hedychium with 2spp., Kaempferia with 3 spp., Zingiber with 5spp. and Costus with 2 spp. As most of the gingers are medicinally important, they are utilised by the local people for various diseases. For this purpose gingers are greatly worked by the pharmacists.

\section{ACKNOWLEDGEMENTS}

The authors are very much thankful to students and the local people of this region for their support in collecting the plants.

\section{REFERENCES}

Das S, Mondal P \& Zaman MK (2013) Curcuma caesia Roxb. and it's medicinal uses: a review. International Journal of Research in Pharmacy and Chemistry 3(2): 370-375.

Gamble JS \& Fischer CEC (1915-36) Flora of Presidency of Madras (3 vol.). London (Reprinted in 1957).

Kirtikar KR \& Basu BD (2003) Indian medicinal plants-Volume II. International Book Distributors, Dehradun, India.

Pullaiah T (1998) Flora of Andhra Pradesh (vol. III). Scientific Publishers, Jodhpur. India.

Rao RS \& Sriramulu H (1986) Flora of Srikakulam district, Andhra Pradesh, India, (Flora of India series). 
Indian Botanical Society, Meerut.

Sharma BD, Karthikeyan S \& Singh NP (1996) Flora of Maharashtra state, Monocotyledons, Botanical Survey of India, Ministry of Environment. Government of India.

Sirirugsa P (1999) Thai Zingiberaceae : Species Diversity And Their Uses. Available from: http://www.iupac.org/symposia/proceedings/phuket97/sirirugsa.html (accessed: 15 Jul. 2017).

SubbaRao GV \& Kumari GR (2008) Flora of Visakhapatnam District, Andhra Pradesh (vol. II). Botanical Survey of India, Ministry of Environment. Government of India.

The Plant List (2017) Available from: http://www.theplantlist.org (accessed 09 Jun. 2017)

Venkaiah M (2004) Studies on the Vegetation and Flora of Vizianagaram District, Andhra Pradesh. Andhra University, Visakhapatnam. 